PERLINDUNGAN HUKUM BLOGGER BERITIKAD BAIK

TERHADAP DOMINE NAME MEREK TERKENAL DARI DUGAAN

PEMBONCENGAN REPUTASI (PASSING OFF)

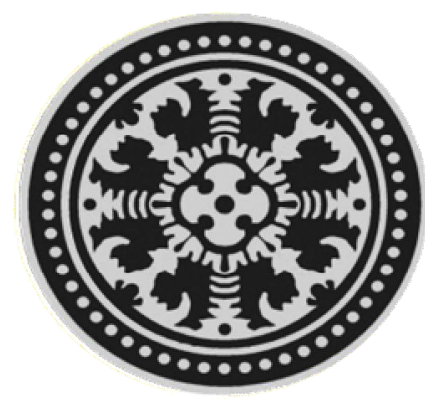

\author{
DESY KUSUMA WARDHANI \\ 1090561048 \\ HUKUM BISNIS
}

\author{
PROGRAM PASCASARJANA \\ MAGISTER ILMU HUKUM \\ UNIVERSITAS UDAYANA \\ DENPASAR
}

2012 


\title{
PERLINDUNGAN HUKUM BLOGGER BERITIKAD BAIK TERHADAP DOMINE NAME MEREK TERKENAL DARI DUGAAN \\ PEMBONCENGAN REPUTASI (PASSING OFF)
}

Oleh :

\author{
Desy Kusuma Wardhani, SH
}

\begin{abstract}
This Research entitled "Legal Protection Against Blogger Good Faith Domine Name Of Alleged Deception Famous Brand Reputation (Passing Off)". The problem of this study was, first: How does the domain name in a legal setting in Indonesia. Second: What is the legal protection of domain name for blogger's good faith if there are similarities with the domain name famous brand.

This research method using normative methods, the legal research done by examining library materials. Which refers to the legal norms contained in the legislation, international conventions, international agreements and court decisions. The results showed, first: The domain name has been linked closely with the brand and copyright but the domain name is not synonymous with the brand and copyright, as it has a system and registration requirements as well as the recognition of the existence differently. So far there are kekososngan norms that specifically regulate the domain name issue in Indonesia. Until now, the settings used by the international ICANN (Internet Corporation for Assigned Names and Numbers), the competent authority dealing with internet IP Addres, and domain name system management. Second: Legal protection for bloggers acting in good faith if there are similarities regarding the domain name can be a famous brand is preventive legal protection and the protection of repressive laws which refers to the settlement of a litigation matter (referring to the legal protection of IPR, Civil, Criminal and Law ITE) and non-litigation (both ADR and UDRP).
\end{abstract}

Keywords: Legal Protection, Blogger good faith, Domain Name, Passing Off

\section{I.PENDAHULUAN}

Perkembangan Teknologi Informasi dan Komunikasi (TIK) telah mengalami perkembangan yang cukup pesat. Dengan adanya media TIK, seperti internet, telah mengubah jarak dan waktu menjadi sesuatu yang tak terbatas (borderless). Adanya media internet ini, dapat dimanfaatkan bagi para pihak untuk melakukan komunikasi satu sama lain terutama komunikasi dalam kegiatan bisnis. Dengan semakin berkembangnya teknologi, tak jarang para pihak yang melakukan kegiatan bisnis melalui media TIK ini, sering terjadi konflik satu sama lain. Satu diantaranya, yang sering terjadi konflik dalam media internet yaitu mengenai nama domain. Nama domain merupakan suatu alamat dalam 
suatu jaringan komputer atau yang dikenal dengan internet.

Sejalan dengan perkembangan teknologi yang demikian kompleks, pendaftaran mengenai nama domain dalam media internet semakin meningkat dari waktu ke waktu. Seringkali dalam melakukan pendaftaran nama domain terjadi benturan dengan merek-merek dagang. Banyak Kasuskasus terkait dengan nama domain yang telah terjadi di Indonesia, terlebih lagi kasus-kasus nama domain dalam media Internet ini, melibatkan perusahaan-perusahaan besar baik, di dalam negeri maupun di luar negeri. Belum adanya suatu regulasi yang jelas terkait dengan nama domain semakin memperburuk perlindungan hukum terhadap pemilik nama domain. Hal ini dapat saja diakibatkan adanya perubahan-perubahan yang begitu cepat dalam dunia maya. Belum adanya regulasi nama domain ini mengakibatkan terjadi kekosongan hukum. Perlindungan hukum terhadap nama domain mutlak harus dilakukan agar tidak merugikan para pihak dalam media internet.

Nama domain memiliki keterkaitan yang sangat erat dengan merek, tetapi perlu ditegaskan bahwa nama domain tidak identik dengan merek karena meskipun keduanya sama-sama merupakan jati diri suatu produk barang atau jasa, atau suatu nama perusahaan, atau badan hukum lainnya, tetapi memiliki sistem dan syarat-syarat pendaftaran serta pengakuan secara berbeda. Nama domain (domain name) yang digunakan sebagai alamat dan identitas di internet memang memiliki permasalahan tersendiri. Penamaan domain memiliki kaitan erat dengan nama perusahaan (dalam hal ini nama perusahaan juga bertujuan untuk membedakan usaha-usaha keperniagaan tertentu dengan nama perusahaan milik pihak lain, sehingga nama perusahaan adalah senilai tujuannya dengan merek), produk atau jasa (service) yang dimilikinya. Sering kali produk barang atau jasa ini didaftarkan sebagai merek dagang atau merek jasa. Akan tetapi banyak juga domain name blogger yang memiliki kesamaan atau kemiripan dengan domain name merek terkenal, walaupun sesungguhnya domain name blogger tersebut dibuat dengan itikad baik, tidak dimaksudkan untuk membonceng merek terkenal serta bahkan ada yang berupa situs gratis yang dikhususkan untuk pendidikan, hal ini lah yang sering diartikan sebagai pelanggaran terkait adanya dugaan passing off domain name merek terkenal.

Sebagai contoh kasus diantaranya yaitu sony ak.com dan sony.coorp, dimana Somasi dari Sony Corp kepada pengelola SonyAK.com yakni Sony Arianto Kurniawan tentang kemiripan nama domain SonyAK.Com dengan merek "Sony" terjadi beberapa saat yang lalu. Sebagai perusahaan raksasa di dunia, Sony Corp telah berkiprah lama sehingga produknya dikenal banyak orang di dunia. Sony Corp tentu ingin menjaga citra merek "Sony". Oleh karena itu, ketika ada nama domain yang mirip dengan merek 
"Sony" dan membahas seputar Teknologi Informasi apalagi menjadi Knowlegde Center dianggap dapat menimbulkan persepsi yang keliru bagi pengunjung internet sebagai bagian situs resmi dari Sony Corp, padahal kenyataannya tidak demikian. Sony AK merupakan situs pembelajaran gratis di internet yang tidak ada hubungannya dengan Sony corp dan tidak memiliki itikad buruk untuk membonceng reputasi dari domain name Sony Corp dikarenakan bukan merupakan suatu jenis barang dan jasa yang sama. Hal inilah yang menarik penulis untuk merumuskan permasalahan yakni :

1) Bagaimanakah pengaturan domain name dalam hukum di Indonesia?

2) Bagaimanakah perlindungan hukum domain name bagi blogger yag beritikad baik apabila terdapat kemiripan dengan domain name merek terkenal?

Tujuan umum dari penelitian ini adalah untuk mengetahui pengaturan nama domain dalam hukum di Indonesia. Tujuan Khusus dari penelitian ini adalah untuk meneliti perlindungan hukum bagi blogger yang beritikad baik apabila terdapat kemiripan dengan domain name merek terkenal.

\section{Metode Penelitian}

Metode penelitian ini menggunakan metode yuridis normatif, yaitu penelitian hukum yang dilakukan dengan cara meneliti bahan pustaka atau data sekunder. ${ }^{1}$ Yang mengacu kepada norma-norma hukum yang terdapat dalam peraturan perundang-undangan, konvensi internasional,perjanjian internasional dan putusan-putusan Pengadilan. ${ }^{2}$ Penelitian ini dilakukan terhadap berlakunya asas - asas hukum dalam perlindungan hukum blogger beritikad baik terhadap domain name merek terkenal dalam dugaan pemboncengan reputasi (passing off).

\section{HASIL DAN PEMBAHASAN}

\section{Tinjauan Perlindungan HKI}

Pencipta memiliki hak moral untuk menikmati hasil ciptaannya, termasuk didalamnya keuntungan yang dihasilkan oleh keintelektualnya. ${ }^{3}$ Karena itu Thomas Aquinas selaku salah satu pelopor hukum alam merupakan hukum akal budi, hanya diperuntukan bagi mahluk yang rasional. Thomas Aquinas juga menyatakan bahwa hak untuk memperolah kepemilikan adalah salah satu dari persoalan-persoalan yang diserahkan hukum alam kepada negara. Sebagai badan yang tepat untuk mengatur kehidupan sosial,

1 Soerjono Soekanto dan Sri Mamudji, 2009, Penelitian Hukum Nornatif Suatu Tinjauan Singkat, Raja Grafindo Persada, Jakarta, h.13.

2 Sunaryati Hartono, 1994, Penelitian Hukum di Indonesia pada Akhir abad ke-20, PT.Alumni, Bandung, h. 143.

${ }^{3}$ Effendy Hasibuan, 2003, Perlindungan Merek, UI Pers, Jakarta, h.508. 
artinya hak milik pribadi mempunyai fungsi sosial. $^{4}$

Teori Hak Kekayaan Intelektual (HKI) sangat dipengaruhi oleh pemikiran John Locke tentang hak milik. Dalam bukunya, Locke menyatakan bahwa hak milik dari seorang manusia terhadap benda yang dihasilkannya itu sudah ada sejak manusia lahir. Benda dalam pengertian disini tidak hanya benda yang berwujud tetapi juga benda yang abstrak, yang disebut dengan hak milik atas benda yang tidak berwujud yang merupakan hasil dari intelektualitas manusia ${ }^{5}$.

Paparan ini memberikan pemahaman bahwa HKI adalah masuk wilayah hukum yang mana pusat perhatiannya pada hak hukum yang diasosiasikan dengan upaya kreatif atau reputasi dan good will yang bernilai komersial.

“.....IP (Intellectual Property) right at least for patent and copyright may be considered rights in ideal object it is important to point out that ownership of an idea or ideal object affectively give the IP owners a property right in every physical embodiment of that work or invention". 6

(..... hak kekayaan intelektual setidaknya untuk paten dan hak cipta dapat dianggap hak dalam

\footnotetext{
${ }^{4}$ Friedman, 1993, Teori dan Filsafat Hukum-Telaah Kritis Atas Teori-Teori Hukum, PT.RajaGrafindo, Jakarta, h.77.

${ }^{5}$ Syafrinaldi, 2010, Hukum Tentang Perlindungan Hak Milik Intelektual Dalam Menghadapi Era Globalisasi, UIR Press, Jakarta, h.77.

${ }^{6}$ N.Stephen Kinsela, 2008, Againts Intellectual Property, Ludwig von Mises Institute, USA,p-14-15.
}

obyek yang ideal adalah penting untuk menunjukkan bahwa kepemilikan dari sebuah ide atau benda yang ideal afektif memberikan kekayaan intelektual pemilik hak properti dalam setiap perwujudan fisik atau penemuan.)

Hukum yang baik adalah hukum yang mencerminkan nilai-nilai yang hidup dalam masyarakat.

Seperti dalam mahzab Sociological Jurisprudence yang memfokuskan diri pada pentingnya Living Law atau hukum yang hidup dalam masyarakat. Roscoe Pound yang merupakan salah satu penganut mahzab Sociological Jurisprudence menyatakan bahwa hukum itu adalah a tool of social engineering atau sebagai alat perubahan sosial. ${ }^{7}$ Teori hukum pembangunan lebih luas jangkauanya daripada teori dari Roescoe Pond (law as a tool of social engineering) karena lebih menonjolkan peraturan perundangundangan dalam proses pembaharuan hukum di Indonesia. Seperti yang diungkapkan oleh Richard Hartzler mengenai arti kata dari social engeneering bertujuan untuk kesejahteraan manusia yakni ${ }^{8}$ :

As a verb, "engineer" can mean "to lay out, to construct,....(or) to guide the course of ; to manage; as, to

\footnotetext{
${ }^{7}$ Lili Rasjidi dan Ira Rasjidi, 2001, Dasar-dasar Filsafat dan Teori Hukum, PT. Citra Aditya Bakti, Bandung, h.66.

8 H.Richard Hartzler \& Harry.T.Allan, 1969, Introduction To Law : A Functional Approach, Scott Foresman Company, Atlanta, p.1.
} 
engineer a bill through congress." The word "social" as an adjective, can be used in the sense of "pertaining to the welfare of human society" in a context such as "society as an organism or as a group of interrelated interdepemdent persons as a social order." It is in this sense that the words social engineering are employed in this book. Thus, a "social engineer" manages, or guides in such a manner as to effect the welfare of society, and "social enggineering" is a conscious creating and building to promote human welfare.

(Sebagai kata kerja, "engineer" dapat berarti "untuk lay out, untuk membangun, .... (atau) untuk memandu perjalanan, untuk mengelola, sebagai, untuk insinyur tagihan melalui kongres." Kata "sosial" sebagai kata sifat, dapat digunakan dalam arti "yang berkaitan dengan kesejahteraan masyarakat manusia" dalam konteks seperti "masyarakat sebagai suatu organisme atau sebagai sekelompok orang interdepemdent saling terkait sebagai tatanan sosial." Ini adalah dalam pengertian ini bahwa rekayasa sosial kata dipekerjakan dalam buku ini. Dengan demikian, "engineer sosial" mengelola, atau panduan sedemikian rupa untuk mempengaruhi kesejahteraan masyarakat, dan "engineering yang sosial" adalah menciptakan kesadaran dan membangun untuk mempromosikan kesejahteraan manusia.)

Selanjutnya adalah Teori pengayoman ini dikemukakan oleh Suharjo (Mantan Menteri Kehakiman). Teori ini pada intinya menegaskan tujuan hukum adalah untuk mengayomi manusia baik secara aktif maupun pasif. Secara aktif dimaksudkan sebagai upaya untuk menciptakan suatu kondisi kemasyarakatan yang manusiawi dalam proses yang berlangsung secara wajar. Sedangkan yang dimaksud secara pasif adalah mengupayakan pencegahan atas upaya yang sewenang-wenang dan penyalahgunaan hak secara tidak adil. ${ }^{9}$ Selanjutnya terkait dengan fungsi hukum Suhardjo mengemukakan pula bahwa fungsi hukum adalah untuk mengayomi atau melindungi manusia dalam bermasyarakat, dan berbangsa, serta bernegara, baik jiwa dan badannya maupun hak-hak pribadinya, yaitu hak azasinya, hak kebendaannya maupun hak perorangannya. ${ }^{10}$

\section{Blogger Beritikad Baik Serta Dugaan Pemboncengan Reputasi (Passing Off) Domain Name Merek Terkenal}

Blog adalah kependekan dari Weblog, istilah yang pertama kali digunakan oleh Jorn Barger pada bulan Desember 1997. Para pembuat blog dinamakan Blogger. Melalui Blognya, kepribadian Blogger menjadi mudah dikenali berdasarkan topik apa yang disukai, apa tanggapan terhadap link-link yang di pilih dan isu-isu didalamnya. Oleh karena itu Blog bersifat sangat personal. Blogger adalah objek pelaku dari sebuah blog, dengan kata lain Blogger (terlepas dari aksi google yang membeli domain blogger.com untuk layanan

\footnotetext{
9 Abdul Manan, 2005, Aspek-Aspek Pengubah Hukum, Kencana, Jakarta, h.23.

${ }^{10}$ Ibid.
} 
blognya) adalah orang-orang yang senantiasa menulis dan mengupdate blognya. ${ }^{11}$

UU Merek tidak memberikan batasan pengertian dan penjelasan mengenai itikad baik. Oleh sebab itu, dirujuk kepada beberapa yurisprudensi Mahkamah Agung telah mempertimbangkan mengenai batasan itikad baik tersebut bahwa dalam putusan No.1269 L/Pdt/1984 tanggal 15 Januari 1986, putusan No.220 PK/Perd/1981 tanggal 16 Desember 1986 dan putusan No.1272 K/Pdt/1984 tanggal 15 Januari 1987, Mahkamah Agung berpendapat bahwa pemilik merek yang beritikad tidak baik karena telah menggunakan merek yang terbukti sama pada pokoknya atau sama pada keseluruhannya dengan merek pihak lawannya. ${ }^{12}$ Pengertian beritikad baik tidak boleh bertentangan dengan syarat-syarat yang ditetapkan Pasal 6 UU Merek, pendaftaran merek harus dilakukan dengan itikad baik untuk menggunakannya pun harus dengan itikad baik. Masalah itikad baik tersebut juga akan timbul jika seseorang telah memakai suatu merek dalam periode sebelumnya, jika seseorang itu dapat membuktikan bahwa dirinya sudah menggunakan mereknya walaupun belum didaftarkannya, maka usaha pendaftaran

\footnotetext{
${ }^{11}$ visualbasicfree.blogspot.com/2012/07/pengertianblogger.html diunduh tanggal 15/09/12

12 Gatot Supramono, 2005, Pendaftaran Merek Berdasarkan Undang-Undang Nomor 19 Tahun 1992, Jakarta, PT. Raja Grafindo Persada, h. 26.
}

merek tersebut oleh orang lain dapat dicegah berdasarkan prinsip "itikad tidak baik".

Dalam Pasal 1 angka 20 UndangUndang No. 11 Tahun 2008 tentang Informasi dan Transaksi Elektronik ("UU ITE"), domain name adalah alamat internet penyelenggara negara, orang, badan usaha, dan/atau masyarakat, yang dapat digunakan dalam berkomunikasi melalui internet, yang berupa kode atau susunan karakter yang bersifat unik untuk menunjukkan lokasi tertentu dalam internet.

Merek terkenal biasa juga disebut sebagai "well known mark" merek jenis ini mempunyai reputasi yang tinggi karena lambangnya memilik kekuatan untuk menarik perhatian. Di Indonesia, penentuan merek terkenal didasarkan pada pertimbangan sebagaimana dimaksud dalam penjelasan pasal 6 ayat (1) huruf $b$ undang-undang tentang merek yang menyatakan bahwa penolakan permohonan yang mempunyai persamaan pada pokoknya atau keselurah dengan merek terkenal, untuk barang dan atau jasa yang sejenis dilakuka dengan memperhatikan pengetahuan umum masyarakat mengenai merek tersebut di bidang usaha yang bersangkutan.

Passing off dapat dikatakan sebagai tindakan yang mencoba meraih keuntungan melalui jalan pintas dengan segala macam cara dan dalih dengan melanggar etika bisnis, norma kesusilaan maupun hukum. Perbuatan untuk meraih keuntungan tersebut dengan cara 
membonceng reputasi merek terkenal yang pada dasarnya dilandasi oleh itikad tidak baik yaitu dengan cara menyesatkan konsumen ${ }^{13}$.

\section{Pengaturan Domain Name Dalam} Hukum Di Indonesia

Merek dan domain name adalah merupakan suatu hal yang berbeda. Namun, domain name merupakan salah satu representasi dari suatu merek. Menurut UU Merek, yang dimaksud Merek adalah tanda berupa gambar, nama, kata, huruf-huruf, angka-angka, susunan warna atau kombinasi dari unsur-unsur tersebut yang memiliki daya pembeda dan digunakan dalam kegiatan perdagangan barang atau jasa.

Domain name yang berupa nama, susunan huruf, kata atau angka, dan seringkali juga dikombinasikan dengan susunan warna dan gambar, dapat dikategorikan sebagai merek apabila memiliki daya pembeda dengan domain name lain dan digunakan dalam kegiatan perdagangan barang atau jasa. Domain name sebagai merek ini akan berfungsi sebagai tanda pengenal untuk membedakan dengan domain name lain dan juga sebagai alat promosi bagi produk yang dihasilkannya. Untuk mendapatkan hak atas merek, pemilik domain name harus mengajukan permintaan pendaftaran merek ke Kantor Merek di Departemen Hukum dan

\footnotetext{
${ }^{13}$ Muhammad Jumhana dan R. Jubaidillah, 1997, "Hak Milik Intelektual", Citra Aditya Bakti, Bandung, h. 235 .
}

Perundang-undangan RI. Permintaan pendaftaran merek dapat ditolak apabila setelah dilakukan pemeriksaan ternyata mempunyai persamaan pada pokoknya atau keseluruhannya dengan merek milik orang lain yang sudah terdaftar lebih dahulu untuk barang dan atau jasa yang sejenis. Domain name sebagai merek terdaftar akan mendapat perlindungan hukum untuk jangka waktu 10 (sepuluh) tahun dan berlaku surut sejak tanggal penerimaan pendaftaran merek bersangkutan. Atas permintaan pemilik merek jangka waktu perlindungan merek terdaftar dapat diperpanjang setiap kali untuk jangka waktu yang sama.

Antara nama domain (domain name) dengan merek pada umumnya termasuk merek dagang (trademark), terdapat perbedaan sebagai berikut, nama domain bukan merupakan hak milik yang dilindungi, sebagai akibatnya, walaupun telah diberikan, nama domain masih tetap dapat dituntut, sangat unik dan hanya bisa terdapat satu diseluruh dunia (tidak bisa ada nama domain yang persisi sama untuk dua subjek hukum yang berbeda), lebih bersifat deskriptif, hanyalah alamat computer, pemilik merek mendapat perlindungan perlindungan hukum atas merek tersebut, merek yang sama dapat dimiliki oleh dua orang yang berbeda, sepanjang tidak melindungi jenis-jenis barang yang sama dalam satu kelas atau bukan karena berasal dari negara yang sama, harus memiliki daya pembeda yang membedakan merek tersebut 
untuk barang sejenis, yang diproduksi oleh perusahaan-perusahaan yang berbeda, dapat berperan sebagai indikasi asal suatu barang.

Nama domain tersebut mempunyai dan termasuk rezim hak kekayaan intelektual, khususnya merek. Karena nama domain dimaksudkan sebagai suatu yang mudah di ingat, dikenal dan dikaitkan dengan pemiliknya, maka nama domain bisa dianggap sebagai sesuatu yang mempunyai fungsi dan tujuan yang sama dengan fungsi dan tujuan merek. Penamaan domain berkaitan erat dengan nama perusahaan dan atau produk (service) yang dimilikinya. Adakalanya suatu nama domain dapat dilindungi dengan hukum merek, karenanya nama domain menjadi kepemilikan dan merupakan salah satu bentuk atau bidang hak kekayaan intelektual. Oleh karena itu, syarat-syarat yang harus dipenuhi agar gugatan ganti rugi dan atau penghentian semua perbuatan yang berkaitan dengan penggunaan merek berdasarkan pasal $76 \mathrm{UU}$ No.15 tahun 2001 tentang merek serta tuntutan pidana berdasarkan pasal 90 No. 15 Tahun 2001 Tentang Merek, dapat digunakan adalah sebagai berikut: Pertama, bukti bahwa penggugat memiliki hak yang sah atas merek terkait, melalui pendaftaran atau pemakaian pertama. Tanggal pendaftaran atau pemakaian merek pertama ini harus lebih dulu dari tanggal efektif pendaftaran nama domain pihak registrant (Tergugat) tersebut. Kedua, nama domain tersebut memiliki persamaan keseluruhannya atau pada pokoknya (identical or confusingly similar) dengan merek Penggugat (pihak yang merasa dirugikan). Ketiga, pihak registrant (Tergugat) tidak cuma sekedar mendaftarkan nama domain tersebut, tetapi juga menggunakannya untuk memperdagangkan barang/jasa yang sejenis. Namun untuk merek terkenal, unsur persamaan jenis barang/jasa dapatlah dikesampingkan. Keempat, pihak registrant (Tergugat) telah mendaftarkan dan memakai nama domain dengan itikad buruk.

Lebih jauh nama domain (domain name) tidak sama dengan merek pada umumnya termasuk merek dagang (trademark), karena sangat berbeda konstruksi hukumnya ataupun nuansa hukum yang mendasarinya (legal sense), dengan uraian singkat sebagai berikut: Nama Domain Merek yakni, eksistensinya berfungsi sebagai alamat dan nama sistem jaringan komputerisasi dan telekomunikasi, lebih bersifat sebagai alamat yang diberikan oleh masyarakat hukum pengguna internet, daripada sebagai suatu properti, asasnya adalah berlaku universal yakni "First Come First Served Basis", tidak ada pemeriksaan substantif, sepanjang tidak dapat dibuktikan beritikad tidak baik, perolehan nama domain bukanlah suatu tindakan yang melawan hukum. Eksistensinya berfungsi sebagai daya pembeda dalam lingkup perindustrian dan perdagangan, lebih bersifat sebagai properti karena merupakan kreasi intelektual manusia yang dimintakan haknya kepada negara untuk kepentingan 
industri dan perdagangan, asasnya ada menganut "First to Filed" dan ada yang menganut "First to Used", harus ada pemeriksaan subtantif, sepanjang tidak diberikan lisensi oleh yang berhak, penggunaan merek merupakan pelanggaran.

Nama domain memiliki keterkaitan erat dengan merek, tetapi nama domain tidak identik dengan merek meskipun keduanya sama-sama merupakan jati diri suatu produk barang atau jasa, atau suatu nama perusahaan atau badan hukum lainnya, karena memiliki sistem dan syarat-syarat pendaftaran serta pengakuan eksistensi secara berbeda.

Menurut Undang-undang Nomor 19 Tahun 2002 tentang Hak Cipta, yang dimaksud dengan Ciptaan adalah hasil setiap karya pencipta dalam bentuk yang khas dan menunjukan keasliannya dalam lapangan ilmu pengetahuan, seni dan sastra. Sedangkan Hak Cipta adalah hak khusus bagi pencipta maupun penerima hak untuk mengumumkan atau memperbanyak ciptaannya maupun memberi izin untuk itu dengan tidak mengurangi pembatasan-pembatasan menurut peraturan perundang-undangan yang berlaku. Ciptaan yang mendapat perlindungan dari UndangUndang Nomor 19 Tahun 2002 tentang hak cipta adalah ciptaan dalam bidang ilmu pengetahuan, seni dan sastra yang meliputi antara lain: buku atau hasil karya tulis lainnya, program komputer, pamflet, ceramah atau pidato yang diwujudkan dengan cara diucapkan, ciptaan lagu atau musik, drama, tari, seni rupa dalam segala bentuk, arsitektur, fotografi, sinematografi, terjemahan, dan sebagainya.

Domain name merupakan sebuah karya cipta yang diwujudkan dalam suatu susunan huruf, angka atau kata yang khas, sehingga dapat dikategorikan sebagai suatu hasil karya tulis. Apabila domain name tersebut dalam tampilannya dipadu dengan gambar atau susunan warna maka dapat saja dikategorikan sebagai suatu bentuk hasil seni lukis/gambar. Undang-undang nomor 19 tahun 2002 tentang hak cipta memberikan perlindungan terhadap domain name untuk dua kategori tersebut adalah selama hidup pencipta domain name tersebut, ditambah 50 tahun setelah penciptanya meninggal dunia.

Domain Name juga diatur oleh Undang-Undang No. 11 Tahun 2008 tentang Informasi dan Transaksi Elektronik. Dalam Bab VI Disebutkan mengenai Nama Domain, Hak Kekayaan Intelektual, Dan Perlindungan Hak Pribadi.

Pasal 23

(1) Setiap penyelenggara negara, Orang, Badan Usaha, dan/atau masyarakat berhak memiliki Nama Domain berdasarkan prinsip pendaftar pertama.

(2) Pemilikan dan penggunaan Nama Domain sebagaimana dimaksud pada ayat (1) harus didasarkan pada iktikad baik, tidak melanggar 
prinsip persaingan usaha secara sehat, dan tidak melanggar hak Orang lain.

\section{(3) Setiap penyelenggara negara, Orang,} Badan Usaha, atau masyarakat yang dirugikan karena penggunaan Nama Domain secara tanpa hak oleh Orang lain, berhak mengajukan gugatan pembatalan Nama Domain dimaksud.

\section{Pasal 24}

(1) Pengelola Nama Domain adalah Pemerintah dan/atau masyarakat.

(2) Dalam hal terjadi perselisihan pengelolaan Nama Domain oleh masyarakat, Pemerintah berhak mengambil alih sementara pengelolaan Nama Domain yang diperselisihkan. (3) Pengelola Nama Domain yang berada di luar wilayah Indonesia dan Nama Domain yang diregistrasinya diakui keberadaannya sepanjang tidak bertentangan dengan Peraturan Perundang-undangan.

(4) Ketentuan lebih lanjut mengenai pengelolaan Nama Domain sebagaimana dimaksud pada ayat (1), ayat (2), dan ayat (3) diatur dengan Peraturan Pemerintah.

Penjelasan :

Pasal 23 Ayat (1) adalah Nama Domain berupa alamat atau jati diri penyelenggara negara,

Orang, Badan Usaha, dan/atau masyarakat, yang perolehannya didasarkan pada prinsip pendaftar pertama (first come first serve). Prinsip pendaftar pertama berbeda antara ketentuan dalam Nama Domain dan dalam bidang hak kekayaan intelektual karena tidak diperlukan pemeriksaan substantif, seperti pemeriksaan dalam pendaftaran merek dan paten. Pada Ayat (2) Yang dimaksud dengan "melanggar hak Orang lain", misalnya melanggar merek terdaftar, nama badan hukum terdaftar, nama Orang terkenal, dan nama sejenisnya yang pada intinya merugikan Orang lain.

Ayat (3) Yang dimaksud dengan "penggunaan Nama Domain secara tanpa hak" adalah pendaftaran dan penggunaan Nama Domain yang semata-mata ditujukan untuk menghalangi atau menghambat Orang lain untuk menggunakan nama yang intuitif dengan keberadaan nama dirinya atau nama produknya, atau untuk mendompleng reputasi Orang yang sudah terkenal atau ternama, atau untuk menyesatkan konsumen.

Sejauh ini tidak ada satu peraturan di Indonesia yang sacara khusus mengatur masalah domain name. Sampai saat ini pengaturan mengenai domain name adalah pengaturan ICANN (Internet Corporation for Assigned Names and Numbers), otoritas internet yang berwenang menangani masalah IP Addres, serta manajemen sistem domain name. Sehingga segala akibat hukum yang timbul dari penggunaan nama domain sudah sepatutnya tunduk pada ketentuan yang telah ditetapkan oleh badan tersebut tersebut. Jika terjadi sengketa nama domain maka tunduk 
pada UDRP (Uniform Dispute Resolution Policy), yang merupakan ketentuan ICANN tentang penyelesaian sengketa domain name. Namun hingga kini belum terlihat bahwa Indonesia akan meratifikasi UDRP sebagai undang-undang.

\section{Perlindungan Hukum Domain Name} Blogger Beritikad Baik

Pada perkembangananya, sering
muncul tindakan penyalahgunaan nama domain dan menyebabkan timbulnya sengketa dalam dunia bisnis tersebut. Upaya penyelesaian sengketa nama domain termaksud dapat ditempuh dengan beberapa cara yaitu secara litigasi dan non litigasi. Penyelesaian sengketa secara litigasi berarti penyelesaian sengketa yang ditempuh melalui pengadilan dengan memperhatikan hukum acara yang berlaku, sedangkan penyelesaian sengketa secara non litigasi merupakan penyelesaian sengketa secara alternatif artinya penyelesaian sengketa itu dilakukan di luar pengadilan, antara lain dapat dilakukan dengan cara negosiasi, mediasi, konsiliasi atau arbitrase yang dapat ditempuh melalui perantaraan lembaga arbitrase seperti Badan Arbitrase Nasional Indonesia (BANI) atau lembaga arbitrase lainnya atau penyelesaian sengketa melalui ICANN berdasarkan kebijakan UDRP. $^{14}$

\footnotetext{
${ }^{14}$ M. Arsyad Sanusi,2001, E-Commerce, Hukum Dan Solusinya, PT.Mizan Grafika Sarana, Bandung, ,h. 14.
}

Salah satu contoh kasus domain name yang pernah terjadi adalah kasus Sony Corp melawan Sony AK. Kasus ini bermula dari adanya somasi dari sony coorp Pada 22 Januari 2010 merupakan pertama kali sony ak mendapatkan surat somasi ke rumah dan melalui email 3 Maret 2010. Domain sony ak telah didaftarkan sejak 28 Juli 2003 (www.whois.sc/sony-ak.com), Sony ak mengisi sony-ak.com dengan tulisantulisannya pribadi, karena kompetensi nya di bidang IT dan hobby menulis, dan kesukaannya knowledge sharing maka ia menulis segala sesuatu mengenai IT pada domain tersebut, Situs sony-ak.com ia beri label Sony AK Knowledge Center karena sebagai media knowledge sharing pribadi dengan semua pembaca online di seluruh dunia, Sony AK Knowledge Center mengandung kata SONY tapi Sony AK Knowledge Center bukanlah merek, Sony AK Knowledge Center tidak berbadan hukum dan juga tidak ada niat untuk membuat badan hukum atas label tersebut, Sony AK Knowledge Center juga bukan organisasi dan tidak mendapat profit apa-apa, Sony AK Knowledge Center juga tidak berhubungan dengan produk-produk "SONY Corporation" Jepang. Sony ak juga tidak ada niat untuk membuat bingung para audience dengan menanggapi, Sony ak tidak melakukan promosi apapun sejak situs ini berdiri tahun 2003, semua berawal dari internet dan masuk search engine. Akan tetapi, pemilik blog 
www.sony-ak.com jelas memiliki kepentingan yang sah karena pemilik tidak bermaksud untuk mendompleng reputasi Sony Corporation untuk suatu kepentingan komersial (fair use), justru sebaliknya blog tersebut dibuat sebagai kontribusi dalam dunia pendidikan IT (information technology) secara gratis. Lebih lanjut, unsur kata "sony" dalam blog tersebut diambil dari nama sang pemilik blog yaitu Sony Arianto Kurniawan. Selain itu, dalam blog tersebut tidak ada satu pun bahasan yang berhubungan dengan Sony Corporation, bahkan sang pemilik blog dengan iktikad baik menambahkan keterangan yang menjelaskan bahwa blog tersebut tidak terkait ataupun terafiliasi dengan Sony Corporation. ${ }^{15}$

Perlindungan hukum didefinisikan sebagai suatu upaya untuk melindungi kepentingan individu atas kedudukannya sebagai manusia yang mempunyai hak untuk menikmati martabatnya, dengan memberikan kewenangan padanya untuk bertindak dalam rangka kepentingannya tersebut. Dalam kaitannya dengan pengertian tersebut maka dalam studi kasus ini dapat diuraikan bahwa perlindungan hukum yang diberikan kepada blogger beritikad baik yang dalam hal ini adalah sony ak dapat diuraikan menurut jenis perlindungan hukum, yaitu:

\section{A. Perlindungan Hukum Preventif}

\footnotetext{
${ }^{15}$ http://www.hukumonline.com/klinik/detail/cl6558/kas us-nama-domain diunduh pada tanggal 15/0912
}

Perlindungan yang diberikan oleh pemerintah dengan tujuan untuk mencegah sebelum terjadinya pelanggaran. Sebaiknya untuk menghidari adanya sengketa domain name, pendaftar domain name harus menghubungi organisasi pendaftar domain name terlebih dahulu untuk mengetahui apakah domain name telah didaftarkan oleh pihak lain ataupun belum. Beberapa hal yang sekiranya penting untuk diperhatikan dalam kepemilikan suatu domain name, yaitu, apakah penggunaan domain name memiliki kemiripan pada pokoknya ataupun pada keseluruhan dengan suatu merek lain yang sudah lebih dahulu dipergunakan; apakah pemegang domain name mempunyai kepentingan maupun hak yang sah (legitimate rights or interest) atas penggunaan domain name tersebut; dan apakah penggunaan domain name digunakan dan didaftarkan dengan iktikad baik (good faith) sehingga tidak melanggar prinsip hukum.

Oleh karena itu, Internet Corporation for Assigned Names and Numbers (ICANN), sebuah organisasi non-profit yang bertugas mengatur dan mengawasi sistem registrasi dan pemanfaatan nama domain, membuat suatu panduan dalam menyelesaikan perselisihan dalam pemanfaatan nama domain, yaitu Uniform Domain Name Dispute Resolution Policy (UDRP) yang berlaku efektif sejak 26 Agustus 1999. Nama domain dapat dimohonkan pembatalan apabila dianggap telah didaftarkan dengan itikad buruk (bad 
faith). UDRP memberikan panduan sebagai langkah awal untuk menilai apakah nama domain telah didaftarkan dengan itikad buruk (bad faith), yaitu ${ }^{16}$ :

Pertama, pemegang nama domain mendaftarkan nama domain dengan tujuan untuk menjual, menyewakan, atau memindahkan nama domain tersebut kepada pemilik merek terdaftar dengan sejumlah imbalan tertentu, atau menjualnya kepada pesaing dari pemilik merek terdaftar. Kedua, pemegang nama domain dengan sengaja mendaftarkan suatu nama domain untuk menghalangi pemilik merek terdaftar memiliki nama domain sesuai dengan merek yang dimilikinya. Ketiga, pemegang nama domain mendaftarkan suatu nama domain dengan tujuan untuk mengganggu bisnis yang dijalankan oleh pesaing bisnisnya. Keempat, pemegang nama domain secara sengaja berusaha untuk menarik perhatian publik dengan mendaftarkan nama domain yang sama atau mirip dengan merek yang didaftarkan pihak lain, sehingga membingungkan konsumen dari merek tersebut.Suatu pihak dapat mengajukan permohonan pembatalan nama domain melalui lembaga-lembaga yang dibentuk oleh ICANN.

Pengaturan UDRP (Uniform Domain name Dispute Resolution Procedure) yang telah diadopsi oleh WIPO, ICANN dan badanbadan arbitrase internasional dan beberapa

\footnotetext{
${ }^{16}$ http://www.icann.org/en/dndr/udrp/policy.htm diunduh pada tanggal 15/09/12
}

Negara. Pengaturan UDRP adalah suatu proses yang dibentuk oleh Internet Corporation for Assigned Names and Numbers (ICANN) untuk penyelesaian sengketa yang berkaitan dengan pendaftaran internet nama domain. Ketika seorang pendaftar memilih nama domain, pendaftar harus "menyatakan dan menjamin," antara lain, yang mendaftarkan nama "tidak akan melanggar hak atas atau melanggar hakhak dari pihak ketiga," dan setuju untuk melanjutkan ke lembaga arbitrase bila ada klaim atau perselisihan dari pihak ke tiga. Seorang yang membuat pengaduan, dalam acara UDRP diatur harus mampu menunjukkan, membuktikan bahwasanya perbuatan/tindakan dari pihak yang diadukan telah memenuhi tiga unsur ${ }^{17}$ :

1. Nama domain adalah identik atau membingungkan/ mirip dengan merek dagang atau merek di mana pengadu memiliki hak,

2. Pendaftar tidak memiliki hak atau kepentingan-kepentingan sah dalam nama domain,

3. Pendaftar mendaftarkan nama domain dan menggunakannya dengan "itikad buruk."

Dalam UDRP juga dinyatakan dan diatur, terhadap sebuah pengaduan akan ada sebuah panel yang akan mempertimbangkan

\footnotetext{
17 www.ebizzasia.com diunduh pada tanggal 15/09/12
} 
beberapa faktor non-eksklusif untuk menilai ada tidaknya itikad buruk, seperti ${ }^{18}$ :

1. Apakah pendaftar mendaftarkan nama domain terutama untuk tujuan menjual, menyewakan, atau mentransfer nama domain registrasi ke pengadu yang sah adalah pemilik merek dagang atau merek;

2. Apakah pendaftar mendaftarkan nama domain untuk mencegah pemilik merek dagang atau merek mendapatkan nama domain yang sesuai, jika pemilik nama domain telah tampak jelas dalam suatu pola tindakan (perbuatan),

3. Apakah pendaftar mendaftarkan nama domain terutama untuk tujuan mengganggu bisnis pesaing;

4. Apakah dengan menggunakan nama domain, pendaftar telah dengan sengaja berusaha untuk menarik dan untuk memperoleh keuntungan komersial, website berbasis pendaftaran dari penggunanya, menciptakan kemungkinan kerancuan dan kebingungan dengan dalam penyampaian informasi keluhan.

\section{B. Perlindungan Hukum Represif}

Perlindungan hukum represif merupakan perlindungan hukum yang bertujuan untuk menyelesaikan suatu sengketa yang terjadi di dalam kehidupan bermasyarakat, perlindungan ini dimaksudkan apabila telah terjadi sengketa. I. Melalui Jalur Litigasi

\section{a. Berdasarkan Ranah Hukum HKI}

\footnotetext{
${ }^{18}$ Ibid.
}

- Dalam Pengaturan Hak Merek

Sebelumnya, perlu kita tinjau dahulu, apakah yang dimaksud dengan merek. Pengertian merek berdasarkan Undang-undang No. 15 Tahun 2001 Tentang Merek. Dalam Pasal 1 ayat (1) disebutkan sebagai berikut: Merek adalah suatu tanda yang berupa gambar, nama, kata, huruf-huruf, angkaangka, susunan warna atau kombinasi dari unsur-unsur tersebut yang memiliki daya pembeda dan digunakan dalam kegiatan perdagangan barang dan jasa."

Hak merek merupakan hak kebendaan, oleh karena itu hak ini dapat dipertahankan terhadap siapa saja. Hal ini dipertegas dengan diberikannya hak gugat kepada pemegang merek, dan adanya sanksi pidana bagi orang yang melanggar hak tersebut, sebagaimana diatur dalam pasal 76, pasal 90 dan pasal 91 UU No.15 tahun 2001 tentang Merek. Untuk menentukan ada tidaknya indikasi pelanggaran merek dalam domain name sony-ak.com, maka seluruh syarat berikut harus dipenuhi;

a. ada bukti bahwa Sony Corp. memiliki hak yang sah atas merek terkait, yakni melalui pendaftaran atau pemakaian pertama. Tanggal pendaftaran atau pemakaian pertama ini harus lebih dulu dari tanggal efektif pendaftaran domain name tersebut.

b. domain name tersebut memiliki persamaan keseluruhan atau pada pokoknya (identical or confusingly similar) dengan merek pihak yang merasa dirugikan. 
c. pihak pendaftar domain name (registrant) tidak cuma sekadar mendaftarkan domain name tersebut, tetapi juga menggunakannya untuk memperdagangkan barang/jasa yang sejenis. Namun untuk merek terkenal, unsur persamaan jenis barang/jasa dapatlah dikesampingkan.

d. pihak registrant domain name mendaftarkan dan memakai domain name dengan itikad buruk.

\section{- Dalam Pengaturan Hak Cipta}

Undang-undang nomor 19 tahun 2002 tentang hak cipta memberikan perlindungan otomatis kepada para blogger atas isi dari website, blog, dan lain sebagainya dari orang yang suka mempublikasi ulang konten atau atikel milik orang lain tanpa izin. Hukumannya yaitu maksimal 1 tahun penjara serta denda 5 milyar rupiah. Isi situs web yang diberikan perlindungan adalah isi yang original hasil karya sendiri bukan menjiplak/memplagiat hasil ciptaan orang lain. Pendaftaran domain name ke Kantor Hak Cipta di Departemen Hukum dan Perundangundangan RI untuk mendapatkan hak cipta memang bukan merupakan kewajiban, namun demikian sangat dianjurkan untuk mendaftarkan domain name tersebut karena Surat Pendaftaran Ciptaan dari Kantor Hak Cipta dapat dijadikan sebagai alat bukti awal di Pengadilan apabila timbul sengketa dikemudian hari terhadap domain name tersebut. b. Secara Perdata

Perlindungan hukum secara perdata ini dimungkinkan untuk melindungi kepentingan blogger beritikad baik yang dalam hal ini sony ak tentang adanya kemiripan domain name dengan merek terkenal. Yaitu dapat melalui gugatan class action atau gugatan perwakilan yang dilakukan dengan cara menghimpun pemilik domain name Sony lainnya. Hukum Indonesia mengatur Dasar Hukum dan Tata Cara Pengajuan Gugatan :'Dasar hukum gugatan Perdata adalah Pasal 1365 KUHPerdata "Setiap orang yang melakukan perbuatan melanggar hukum dan menimbulkan kerugian pada pihak lain wajib baginya mengganti kerugian itu". Tata cara mengajukan gugatan tuntutan atas ganti kerugian bisa dilakukan dalam bentuk gugatan individual, gugatan perwakilan kelompok (class action), gugatan organisasi (legal standing) maupun gugatan warga negara (citizen law suit)."

Gugatan Perwakilan Kelompok (Class Action) Definisi Class Action PERMA No 1 Tahun 2002 merumuskan Gugatan Perwakilan Kelompok (Class Action) sebagai suatu prosedur pengajuan gugatan, dimana satu orang atau lebih yang mewakili kelompok mengajukan gugatan untuk dirinya sendiri dan sekaligus mewakili sekelompok orang yang jumlahnya banyak, yang memiliki kesamaan fakta atau kesamaan dasar hukum antara wakil kelompok dan anggota kelompoknya. 
Apabila class action diajukan ke pengadilan maka kedudukan dari anggota kelompok adalah sebagai penggugat pasif. Adanya Kerugian yang nyata-nyata diderita Untuk dapat mengajukan class action Baik pihak wakil kelompok (class repesentatif) maupun anggota kelompok (class members) harus benar-benar atau secara nyata mengalami kerugian atau diistilahkan concrete injured parties.

c. Secara Pidana

Perlindungan secara pidana dapat dilihat dari adanya pasal yang menyangkut keadaan yang tidak menyenangkan. Adapun ketentuan hukum yang menjadi dasarnya adalah Pasal 335 ayat (1) KUHP, yaitu barangsiapa memaksa orang lain supaya melakukan sesuatu, tidak melakukan sesuatu atau membiarkan sesuatu, dengan memakai kekerasan, sesuatu perbuatan lain maupun perlakuan yang tidak menyenangkan, atau dengan memakai ancaman kekerasan, sesuatu perbuatan lain maupun perlakuan yang tak menyenangkan, baik terhadap orang itu sendiri atau orang lain, dapat diancam saksi pidana penjara paling lama 1 (satu) tahun.

Pasal 310 dan Pasal 311 KUHP. Demikian salah satu pertimbangan Mahkamah Konstitusi dalam putusan perkara No. 50/PUU-VI/2008 atas judicial review pasal 27 ayat (3) Undang-Undang No. 11 Tahun 2008 tentang Informasi dan Transaksi Elektronik terhadap UUD 1945. Mahkamah Konstitusi menyimpulkan bahwa nama baik dan kehormatan seseorang patut dilindungi oleh hukum yang berlaku, sehingga Pasal 27 ayat (3) Undang-Undang No. 11 Tahun 2008 tentang Informasi dan Transaksi Elektronik tidak melanggar nilai-nilai demokrasi, hak azasi manusia, dan prinsip-prinsip negara hukum. Pasal 27 ayat (3) Undang-Undang No. 11 Tahun 2008 tentang Informasi dan Transaksi Elektronik adalah Konstitusional. Bila dicermati isi Pasal 27 ayat (3) jo Pasal 45 ayat (1) Undang-Undang No. 11 Tahun 2008 tentang Informasi dan Transaksi Elektronik tampak sederhana bila dibandingkan dengan pasal-pasal penghinaan dalam KUHP yang lebih rinci. Oleh karena itu, penafsiran Pasal 27 ayat (3) Undang-Undang No. 11 Tahun 2008 tentang Informasi dan Transaksi Elektronik harus merujuk pada pasal-pasal penghinaan dalam KUHP. Misalnya, dalam Undang-Undang No. 11 Tahun 2008 tentang Informasi dan Transaksi Elektronik tidak terdapat pengertian tentang pencemaran nama baik. Jadi, dalam hal ini perlindungan hukum bagi blogger beritikad baik yang dalam hal ini adalah sony ak tentang adanya somasi maupun dugaan passing off atau pemboncengan reputasi dengan adanya kemiripan domain name dengan merek terkenal, maka pihak blogger dapat mengajukan tuntutan pidana setelah terlebih dahulu membuktikan itikad baik dari domain name blogger, Dengan merujuk Pasal 310 ayat (1) KUHP, pencemaran nama baik diartikan sebagai perbuatan menyerang kehormatan atau nama 
baik seseorang dengan menuduhkan sesuatu hal yang maksudnya terang supaya hal itu diketahui umum.

d. Dalam Pengaturan Undang-undang ITE

Ditinjau dari nama domain "SonyAK.com" memang dapat menimbulkan persepsi yang keliru karena AK merupakan singkatan yang dapat memiliki kepanjangan yang dipersepsikan berbeda oleh pengunjung situs itu, mungkin ada pengunjung yang menganggap AK adalah singkatan nama suatu negara. Hal ini tidak akan menimbulkan persepsi yang keliru bila nama domain yang digunakan seperti "Sony-Ari-Kur.com". Dalam Undang-Undang No. 11 Tahun 2008 tentang Informasi dan Transaksi Elektronik telah diatur mengenai kepemilikan nama domain dan penggunaannya. Dalam Pasal 23 Undang-Undang No. 11 Tahun 2008 tentang Informasi dan Transaksi Elektronik dinyatakan bahwa:

1. Setiap penyelenggara negara, Orang, Badan Usaha, dan/atau masyarakat berhak memiliki Nama Domain berdasarkan prinsip pendaftar pertama.

2. Pemilikan dan penggunaan Nama Domain sebagaimana dimaksud pada ayat (1) harus didasarkan pada iktikad baik, tidak melanggar prinsip persaingan usaha secara sehat, dan tidak melanggar hak Orang lain.

3. Setiap penyelenggara negara, Orang, Badan Usaha, atau masyarakat yang dirugikan karena penggunaan Nama
Domain secara tanpa hak oleh Orang lain, berhak mengajukan gugatan pembatalan Nama Domain dimaksud.

Mengacu pada pasal-pasal tersebut, Sony AK pemilik domain yang dipermasalahkan tidak sedikitpun mempunyai motif ataupun niatan buruk atas pendaftaran nama domain tersebut. Blog dari nama domain sony ak tersebut semuanya berisi artikel-artikel berbagi ilmu pengetahuan yang dilakukan secara pribadi oleh Sony Arianto Kurniawan. Sony-AK.com pun merupakan nama pribadi yang punya domain, dengan huruf $\mathrm{A}$ dan $\mathrm{K}$ merupakan singkatan dari kata-kata Arianto dan Kurniawan pada namanya.

Dalam Pasal 23 ayat (2) Undang-Undang No. 11 Tahun 2008 tentang Informasi dan Transaksi Elektronik secara tegas dinyatakan bahwa pemilikan dan penggunaan Nama Domain harus didasarkan iktikad baik. Hal ini berarti bahwa kemiripan nama domain bukan satu-satunya ukuran untuk men-klaim bahwa terjadi suatu pelanggaran hukum, tetapi harus dilihat pula bagaimana penggunaan nama domain tersebut. Penggunaan nama domain bertitik tolak pada isi atau content yang dimuat dalam nama domain tersebut.

\section{Melalui Jalur Non Litigasi}

Selain penyelesaian gugatan para pihak dapat menyelesaikan sengketa melalui Arbitrase atau Alternatif Penyelesaian Sengketa. Bahkan melalui alternatif 
penyelesaian sengketa mekanisme internasional melalui World Intellectual Property Organization (WIPO) Mediation and Arbitration Center, dengan menggunakan Uniform Domain Name Dispute Resolution Policy ("UDRP") sebagai dasar hukum menetapkan suatu perbuatan sebagai pelanggaran domain name atau tidak. UDRP ini diprakarsai oleh Internet Corporation for Assigned Names and Numbers (ICANN) selaku organisasi internasional yang mengatur kebijakan domain name di dunia. Secara universal telah terdapat Uniform Domain-Name DisputeResolution Policy (UDRP) guna menyelesaikan sengketa-sengketa seputar nama domain. Terdapat tiga penilaian yang memungkinkan suatu nama domain dipindah-tangankan, yaitu: nama domain tersebut mirip dengan suatu merek, pemilik nama domain tersebut tidak memiliki hak atau legitimasi atas nama domain tersebut, pendaftar nama domain tersebut terbukti memiliki niatan yang tidak baik. Layaknya mekanisme alternative dispute resolution (ADR), kebijakan penyelesaian sengketa melalui mediasi dan arbitrasi berdasarkan UDRP di WIPO bersifat terbatas. Sengketa nama domain hanya dapat diajukan sekali saja dan tidak dapat diulang. Di Indonesia, Mekanisme penyelesaian perkara menggunakan cara, yaitu:

(a) Negosiasi: Pihak sony ak atau kuasa hukumnya dapat langsung mengajak pihak sony coorp untuk menyelesaikan masalah dengan suatu proses berkomunikasi. Pihak Sony ak dapat memanfaatkan negosiasi untuk mengabulkan kepentingan pihaknya sehingga dapat ditempuh upaya penyelesaian yang dikehendaki antar pihak.

(b) Mediasi: pihak sony ak dapat meminta bantuan pihak ketiga yang independen untuk bertindak sebagai mediator (penengah) dalam perundingan antara pihak sony ak dengan sony corp. Mediator tersebut bertindak dengan menggunakan berbagai prosedur, teknik, dan keterampilan untuk membantu para pihak dalam menyelesaikan sengketa mereka melalui perundingan. Dalam upaya ini, mediator tidak mempunyai kewenangan membuat keputusan yang mengikat, akan tetapi para pihak didorong untuk membuat keputusan, sehingga bentuk penyelesaiannya adalah akta perdamaian antara para pihak yang berselisih;

(c) Konsiliasi: sony ak dan soy coorp dapat memanfaatkan bantuan pihak ketiga yang independen untuk bertindak sebagai konsiliator (penengah), Pihak ketiga tersebut bertindak sebagai konsiliator (penengah) dengan menggunakan berbagai prosedur, 
teknik, dan keterampilan untuk membantu para pihak dalam menyelesaikan sengketa mereka melalui perundingan. Konsiliator mempunyai kewenangan untuk membuat keputusan yang bersifat anjuran. Oleh karena itu bentuk penyelesaiannya adalah putusan yang bersifat anjuran;

(d) Arbitrase: Pihak sony ak dapat menyerahkan sengketanya dengan satu pihak lain atau lebih kepada satu orang arbiter atau lebih dalam bentuk majelis arbiter ahli yang profesional yang akan bertindak sebagai hakim/peradilan swasta yang akan menerapkan tata cara hukum negara yang berlaku atau menerapkan tata cara hukum perdamaian yang telah disepakati bersama oleh para pihak terdahulu untuk sampai pada putusan yang terakhir dan mengikat.

(e) Mekanisme Arbitrase dan Alternatif Penyelesaian Sengketa (APS) yang Dapat Ditempuh sony ak Mekanisme atau langkah-langkah hukum yang dapat ditempuh oleh sony ak apabila menempuh jalur penyelesaian dengan Alternatif Penyelesaian Sengketa (APS) menurut Pasal 6 UU No. 30 Tahun 1999 tentang Arbitrase dan Alternatif Penyelesaian Sengketa.

\section{PENUTUP}

\section{Simpulan}

Nama domain memiliki keterkaitan erat dengan merek, dengan hak cipta tetapi nama domain tidak identik dengan merek dan hak cipta, karena meskipun keduanya samasama merupakan jati diri suatu produk barang atau jasa, atau suatu nama perusahaan atau badan hukum lainnya, karena memiliki sistem dan syarat-syarat pendaftaran serta pengakuan eksistensi secara berbeda. Walaupun secara singkat UU ITE menjelaskan mengenai apa itu domain name, akan tetapi sejauh ini belum ada satu peraturan di Indonesia yang sacara khusus mengatur masalah domain name atau dengan kata lain masih terdapat kekosongan norma. Sampai saat ini pengaturan yang dipakai oleh dunia internasional ICANN (Internet Corporation for Assigned Names and Numbers), otoritas internet yang berwenang menangani masalah IP Addres, serta manajemen sistem domain name.

Perlindungan hukum bagi blogger yang beritikad baik apabila terdapat kesamaan menyangkut domain name merek terkenal adalah dapat berupa perlindungan hukum preventif dan perlindungan hukum repreif yakni mengacu pada penyelesaian masalah secara Litigasi (mengacu pada perlindungan hukum HKI, Perdata, Pidana dan UU ITE) dan non litigasi (secara ADR dan UDRP).

\section{Saran}


Bagi para pemilik domain name merek terkenal, agar selektif dalam pengambilan keputusan untuk mensomasi suatu domain name blogger yang memiliki kemiripan dengan domain name nya, harus lebih dilakukan penelusuran mengenai itikad dari blogger yang memiliki kemiripan domain

\section{DAFTAR BACAAN}

\section{Buku :}

Abdul Manan, 2005, Aspek-Aspek Pengubah Hukum, Kencana, Jakarta.

Effendy Hasibuan, 2003, Perlindungan Merek, UI Pers, Jakarta.

Friedman, 1993, Teori dan Filsafat HukumTelaah Kritis Atas Teori-Teori Hukum, PT.RajaGrafindo, Jakarta.

Gatot Supramono, 2005, Pendaftaran Merek Berdasarkan Undang-Undang Nomor 19 Tahun 1992, PT. Raja Grafindo Persada,Jakarta.

H.Richard Hartzler \& Harry.T.Allan, 1969, Introduction To Law : A Functional Approach, Scott Foresman Company, Atlanta.

Lili Rasjidi dan Ira Rasjidi, 2001, Dasardasar Filsafat dan Teori Hukum, PT. Citra Aditya Bakti, Bandung.

M. Arsyad Sanusi,2001, E-Commerce, Hukum Dan Solusinya, PT.Mizan Grafika Sarana, Bandung.

Muhammad Jumhana dan R. Jubaidillah, 1997, "Hak Milik Intelektual", Citra Aditya Bakti, Bandung. name tersebut untuk menekan adanya dugan pemboncengan reputasi atau passing off.

Bagi Pemerintah, perlunya segera membuat peraturan yang lebih khusus atau pun berupa peraturan pelaksanan yang mengatur secara rinci tentang domain name serta penyelesaian sengketa yang terjadi.

N.Stephen Kinsela, 2008, Againts Intellectual Property, Ludwig von Mises Institute, USA.

Soerjono Soekanto dan Sri Mamudji, 2009, Penelitian Hukum Nornatif Suatu Tinjauan Singkat, Raja Grafindo Persada, Jakarta.

Sunaryati Hartono, 1994, Penelitian Hukum di Indonesia pada Akhir abad ke-20, PT.Alumni, Bandung.

Syafrinaldi, 2010, Hukum Tentang Perlindungan Hak Milik Intelektual Dalam Menghadapi Era Globalisasi, UIR Press, Jakarta.

\section{Peraturan perundang-undangan :}

Undang-undang No.15 tahun 2001 tentang Merek

Undang-undang No. 19 tahun 2002 tentang

Hak Cipta

Undang-Undang No. 11 Tahun 2008 tentang Informasi dan Transaksi

Elektronik

\section{Internet :}

www.visualbasicfree.blogspot.com/2012/0

7/pengertian-blogger.html 
www.hukumonline.com/klinik/detail/c1655

8/kasus-nama-domain

www.icann.org/en/dndr/udrp/policy.htm

www.ebizzasia.com

\section{BIODATA}

$\begin{array}{ll}\text { Nama } & \text { : Desy Kusuma Wardhani, SH } \\ \text { Alamat } & : \text { Jl. Padang Indah IV No.23 Denpasar } \\ \text { Tempat Bekerja } & :- \\ \text { HP/No.Tlp } & : 08179717087 / 0361-8447107 \\ \text { Email } & \text { :dx_ndr44@rocketmail.com }\end{array}$

